\title{
On Walter E. Grunden's Secret Weapons and World War II: Japan in the Shadow of Big Science
}

\author{
(Modern War Studies.) xi + 335 pp., figs., app., bibl., index. \\ Lawrence: University Press of Kansas, 2005. \$39.95 (cloth)
}

\section{Hiroaki Tanaka}

Received: 9 April 2007 / Accepted: 9 April 2007 /

Published online: 25 January 2008

(C) National Science Council, Taiwan 2008

The Asia-Pacific War caused by Imperial Japan in the first half of the twentieth century is an important topic for the East Asian STS studies. It was an event which vastly changed the interrelationships among science, technology, and society in Japan and the other East Asian countries and areas. And it also affected the postwar developments in these countries and areas in various ways. We cannot fully understand the present STS issues in East Asia without knowing the changing STS interrelationships in the war, but studies on this topic are still in the rudimentary stage.

In Japan since the 1980s the historical studies on wartime science and technology in Japan and its former colonies have been progressing and, in recent years, transnational cooperation with European and Asian scholars has begun, good examples of which are the contributions of Japanese scholars to the publication of this international STS journal.

However, the English-language literature on Japan's wartime science and technology was very scarce, probably because of linguistic barriers on both the Japanese and non-Japanese sides. Grunden's Secret Weapons and World War II is the first English-language book on this topic and is extensively based on numerous Japanese as well as English-language sources available at present.

Walter E. Grunden, associate professor of history at Bowling Green State University, Ohio, USA, studied modern Japanese history, modern Chinese history, and the history of science during his graduate school days at the Ohio State University and the University of California, Santa Barbara. He wrote his Ph.D. thesis in 1998 entitled "Science under the Rising Sun: Weapons Development and the Organization of Scientific Research in World War II Japan." Secret Weapons and World War II is a revised and enlarged version of his Ph.D. thesis, especially

\footnotetext{
H. Tanaka $(\bowtie)$

Department of the Humanities and Social Sciences, Tokyo Denki University,

2-2 Kanda Nishiki-cho, Chiyoda-ku, Tokyo 101-8457, Japan

e-mail: tanakahi@cck.dendai.ac.jp
} 
drawing upon Japanese-language sources collected during his stay in Tokyo in 2001-2002.

Focusing on the development of several advanced, so-called "secret" weapons, Grunden examines science and technology mobilization in Japan during World War II. For comparison, he begins each chapter with an outline of weapons development and science mobilization of the other principal belligerents (the United States, Great Britain, the Soviet Union, and Germany).

In the Introduction, Grunden raises two questions: What impact did science have on the war; and what impact did the war have on science in Japan? Although he says that the latter is "perhaps the more significant and interesting question," the succeeding chapters are concerned with the former question. The discussion about the latter question appears only in the Epilogue.

Chapter 1, "Mobilizing Science and Technology for War," gives an overview of the development of Japan's science and technology policy as well as its science and technology mobilization system from World War I to 1945. Grunden concludes: "Thus, a picture emerges wherein conflict plagued the Japanese system from the macro level of government organization to the micro level of the individual scientist in the laboratory, whether military or civilian. Japan was unable to mobilize its science and technology infrastructure to its full capacity during World War II largely as a result of the polycratic nature of the national government and the ubiquitous interservice rivalry" (p. 46). We might summarize his argument in the following manner: The Japanese failed to mobilize science and technology and were unable to make any advanced weapons. In contrast, the Americans successfully mobilized science and technology and were able to make and use advanced weapons such as atomic bombs, which contributed to the American victory over Japan. This is the impact of science on the war.

From Chapter 2 to Chapter 5, Grunden repeats this story in detail taking examples from the belligerents' efforts to develop a number of advanced weapons during World War II: the atomic bomb (Ch. 2), radar and the "death ray" (Ch. 3), guided missiles and jet aircraft (Ch. 4), and chemical and biological weapons (Ch. 5). The primary sources he used extensively in these chapters are intelligence reports made by various U.S. intelligence units during and after the war, which are now held in archives and libraries in the Unites States. Although he says that he has "attempted to verify information by cross-referencing the Japanese- and English-language sources" (p. 11), most of the Japanese-language sources he used were made not in wartime but after the war. Therefore, some bias coming from that seems to be inevitable. Throughout these chapters, his conclusion is almost always the same: The Westerners succeeded, but the Japanese failed.

In the Epilogue, "The Impact of World War II on Science in Japan," Grunden gives brief accounts of the postwar activities of some Japanese scientists and engineers who conducted wartime research. And he concludes this book with the following suggestion: "The examples given above suggest that there was great continuity in institutions and personnel from the war into the postwar period. In particular, the experience and training gained during the war provided many scientists and engineers the means to make significant contributions to the reconstruction of Japan and its economic growth after the war. One might argue 
that the war, on the whole, had a positive impact on science in Japan, despite even all the tragedies the war had brought about" (p. 204).

Both of the answers to the questions raised in the Introduction seem not to be so original. Arguments on Japan's ineffective science mobilization and prevailing rivalries are found in reports made by the U.S. intelligence officers in 1945. An argument on positive effects of the Japanese wartime experiences and institutions upon the postwar development is found in an article written by the Japanese science historian Hiroshige Tetsu in 1965. Grunden cites these arguments from such old sources without putting those into any new perspectives.

What one might think original is the concept of "Big Science revolution." He argues that "there was no Big Science revolution in Japan as occurred elsewhere in the West during World War II" (p. 5). According to him, Big Science is "a type of science that is necessarily large in scale and scope, but size alone is not the most distinguishing characteristic." It "requires the intersection of three essential elements: science, economy, and the state." The Manhattan Project is a typical example of Big Science.

Is this concept of "Big Science revolution" useful for examining Japan's wartime science and technology mobilization? Grunden tends to select and emphasize negative aspects of wartime Japan in order to argue that there was no Big Science revolution in Japan. But this tendency has him failing to treat fairly not so revolutionary but important changes in Japan's science and technology system during the war. I think this is a major reason why he does not describe positive aspects of Japan's science and technology mobilization in the main chapters, but only "suggests" them in the Epilogue. In addition, a minor reason for that, I think, is that the primary sources he used most often were intelligence reports. Impressed by the Japanese defeat, both U.S. interviewers and Japanese interviewees were probably interested in why Japan failed and the Allies succeeded. Under such interest, positive aspects might have been neglected.

In my opinion, a so-called "Big Science revolution" was also beginning in wartime Japan, for the three elements (science, economy, and the state) were being more and more closely interrelated for wartime R\&D in Japan. In this regard, Japan and Western nations were experiencing the same process in the world history of science.

Grunden's emphasis on Japanese failure and Western success seems to make his international comparison less fruitful. Polycracy and rivalries were not unique to Japan, as he also admits in his book. If he had examined both common and different features in the belligerents' science mobilization more exactly, his comparison would have been more fruitful.

Such analytical weakness aside, Grunden's Secret Weapons and World War II is a very informative work on wartime science and technology mobilization in Japan, with more than 100 pages of tables, notes, bibliography, and index. Although we cannot use this book as a fully reliable reference book, because of some mistakes especially in identifying and understanding a large number of organizations with similar names and complicated interrelationships, this book will continue to serve as an indispensable guide for not only non-Japanese but also Japanese scholars studying Japan's wartime science and technology mobilization. 
Recently the conditions for transnational research cooperation are getting better. For example, not mentioned in Grunden's book, the Japan Center for Asian Historical Records (JACAR) of the National Archives of Japan has provided an extremely large number of primary sources related to the Asia-Pacific War as graphic data through the Internet since 2001. The website (http://www.jacar.go.jp/) is written in Japanese, English, Chinese, and Korean, and keyword search is available in Japanese and English. These useful sources are not yet fully utilized by both Japanese and non-Japanese scholars.

I hope Grunden's valuable work will stimulate further interest in Japan's wartime science, technology, and society among scholars worldwide, and transnational cooperation in research will be prospering. 